\title{
Seasonal variation in the size-dependent respiration of mangroves Kandelia obovata
}

\author{
A. T. M. Rafiqul Hoque ${ }^{1}$, Sahadev Sharma ${ }^{1}{ }_{\text {Rempei Suwa }}{ }^{2}$, Shigeta Mori ${ }^{3}$, \\ Akio Hagihara ${ }^{2, *}$
}

\author{
${ }^{1}$ Graduate School of Engineering and Science, University of the Ryukyus, Okinawa 903-0213, Japan \\ ${ }^{2}$ Faculty of Science, University of the Ryukyus, Okinawa 903-0213, Japan \\ ${ }^{3}$ Forestry and Forest Products Research Institute, Tsukuba 306-8687, Japan
}

\begin{abstract}
Despite the potential importance of mangrove forests in carbon cycling and coastal ecology, information on mangrove respiration is scanty. Aboveground nighttime respiration of mangrove Kandelia obovata trees at the northernmost limit of their distribution was measured monthly throughout a year to investigate size-dependence and seasonal variation in respiration. Six sample trees of different sizes were selected from a completely closed canopy stand. Respiration rate $(r)$ of $K$. obovata trees at a monthly mean temperature increased with increasing mass $(m)$. This tendency was described by means of the power function $r=f m^{h}$, where $f$ is the multiplying coefficient and $h$ is the scaling exponent. The exponent values ranged from 0.723 to 1.085 . In the cool winter (dormant season), the exponent $h$ was close to 1.0, while in the warm summer (growing season) the exponent was closer to 3/4. Respiration varies more between seasons in small-sized trees than in large-sized trees. The relative increase in respiration from the winter dormant season to the summer growing season was large in the small-sized trees compared with that in the large-sized trees. The variation in respiration between the 2 seasons is explained on the basis of theories about resource harvesting and transport. Separation of summer respiration into growth and maintenance components is suggested to better understand the dependence of respiration on size and temperature.
\end{abstract}

KEY WORDS: Power function $\cdot$ Mass $\cdot$ Surface area $\cdot$ Summer respiration $\cdot$ Winter respiration

\section{INTRODUCTION}

Forest trees are most important in relation to global climatic change, because they play a prominent role in the global carbon balance (Jarvis 1989). The biomass of a forest ecosystem is large compared with other plant ecosystems, and carbon accumulates in vast amounts in woody components. Net production alone cannot be a stable measure of the potential primary productivity of forest stands, but the best measure of forest productivity should be the gross production (net production plus respiration loss) (Kira 1991). Although there have been hundreds of estimates of whole-stand net primary production around the world, the estimates of wholestand respiration, or even total aboveground respiration, are still fairly rare (Sprugel et al. 1995).
Respiration is a major factor in individual tree, tree stand or ecosystem energy budgets, and estimated to consume anywhere from 30 to $70 \%$ of the total carbon fixed (Hagihara \& Hozumi 1991, Ryan 1991, Sprugel \& Benecke 1991). A large fraction of all carbohydrates that trees assimilate each day is expended as respiration to the atmosphere during the same period (Lambers et al. 2008). Hence, tree respiration is a key component of the global $\mathrm{CO}_{2}$ budget and plays a crucial role in a wide range of ecological phenomena, from the performance of individual trees to global atmospheric $\mathrm{CO}_{2}$ concentrations (Atkin et al. 2005b). Estimating respiration rate is of fundamental importance because it is linked to the rates of many other biological activities (Glazier 2005). The measurement of respiration loss is therefore indispensable in view of the dry mat- 
ter economy of forest stands and the global $\mathrm{CO}_{2}$ budget.

Respiration can be defined as the oxidation of food substrates in living cells, bringing about the release of energy. The energy released is stored as chemical energy in the substrate molecules. Products of respiration include energy and metabolic intermediates that provide carbon skeletons for cell constituents. Both products are required for growth and maintenance of tissues, absorption of mineral nutrients and translocation of organic and inorganic materials (Pallardy 2008). According to Kramer \& Kozlowski (1979), the factors affecting respiration are age and physiological condition of tissues, available substrate, hydration, soil moisture, soil and air temperatures, composition of the atmosphere, injuries and mechanical stimuli, and chemicals. The metabolic rate of individual organisms can vary in response to many intrinsic and extrinsic factors, especially an organism's activity level and the ambient temperature (Glazier 2005). One of the major factors affecting respiratory processes in plants is air temperature. Respiration is expected to be largely under temperature control via kinetic effects on respiratory enzymes (Brown et al. 2004, Atkin et al. 2005a). Indeed, it is typically correlated with natural (daily or seasonal) temperature fluctuations and responsive to short-term temperature manipulations over time scales of minutes or hours (Hagihara \& Hozumi 1991, Larcher 2003, Bruhn et al. 2008).

Among different forest types, mangroves have a significant effect on the coastal environment. The carbon fixation capacity of mangrove forests is higher than that of terrestrial forests (Christensen 1978, Clough 1998). For this reason, mangroves are considered an important carbon sink in coastal ecosystems (Ong 1993). However, despite their potential importance, there are surprisingly very few respiration measurements for mangroves (Alongi 2009). Reports on mangrove respiration with long-term field data are scanty (Hoque et al. 2009). Although there are quite a few measurements on mangrove respiration from laboratory experiments, there is no information regarding aboveground mangrove respiration in the field.

Mangroves are almost exclusively tropical, with some outliers in subtropical latitudes, notably southern Florida, South Africa, Australia and southern Japan (Tomlinson 1986). Mangroves in Japan are scattered throughout the Ryukyu Archipelago and reach as far north as Kiire on southern Kyushu. These are the northernmost mangroves in Asia and consist of small stands of Kandelia obovata Sheue, Liu and Yong (Spalding et al. 1997, Sheue et al. 2003). The distribution of mangroves is related to temperature, which is a limiting factor for plant distribution. Since $K$. obovata on Okinawa Island, Japan, is closer to the northern- most limit of their distribution (Spalding et al. 1997), their physiological characteristics may change dramatically with environmental factors, especially temperature. This study attempts to (1) confirm the sizedependence of respiration in mangroves, i.e. the power-functional relationship between respiration and mass of $K$. obovata under field conditions, and (2) examine the monthly change in the exponent of the power-functional relationship throughout a year, i.e. investigate the seasonal variation of the exponent.

\section{MATERIALS AND METHODS}

Study site. This study was carried out at Manko Wetland in the southern part of Okinawa Island, Japan $\left(26^{\circ} 11^{\prime} \mathrm{N}, 127^{\circ} 40^{\prime} \mathrm{E}\right)$. This wetland has been registered under the Ramsar Convention as an important stopover point and wintering area for migratory birds.

On the basis of data from 1997 to 2006 (Okinawa Astronomical Observatory), the warmth index was $220.4 \pm 0.1^{\circ} \mathrm{C}$ month (mean $\left.\pm \mathrm{SE}\right)$, which is within the range of 180 to $240^{\circ} \mathrm{C}$ month of the subtropical region defined by Kira (1991). The mean annual temperature was $23.4 \pm 0.1^{\circ} \mathrm{C}$ the mean monthly minimum temperature of $17.1 \pm 0.3^{\circ} \mathrm{C}$ and the mean monthly maximum temperature of $28.8 \pm 0.2^{\circ} \mathrm{C}$ occurred in January and July, respectively. The mean monthly rainfall was over $100 \mathrm{~mm}$ throughout the year and the mean annual rainfall was $2227 \pm 163 \mathrm{~mm}$.

Sample trees for respiration. Stand age, tree density, mean tree height and mean stem diameter measured at a height of $10 \%$ of the tree height were $12 \mathrm{yr}, 4.50 \mathrm{~m}^{-2}$, $4.31 \mathrm{~m}$ and $5.83 \mathrm{~cm}$, respectively, based on a tree census of a $20 \times 20 \mathrm{~m}$ Kandelia obovata stand carried out in May 2007. Six K. obovata sample trees representing the tree size class distribution were selected for the measurement of nighttime aboveground respiration from the stand, whose canopy is completely closed (Analuddin et al. 2009). The general features of the sample trees are shown in Table 1. Monthly measurements of the sample

Table 1. Kandelia obovata. General features of the sample trees (as of April 2008)

\begin{tabular}{|lcccc|}
$\begin{array}{c}\text { Sample } \\
\text { number }\end{array}$ & $\begin{array}{c}\text { Height } \\
H(\mathrm{~m})\end{array}$ & $\begin{array}{c}\text { Stem diameter } \\
\text { at } H / 10 \\
D_{0.1 \mathrm{H}}(\mathrm{cm})\end{array}$ & $\begin{array}{l}\text { Individual } \\
\text { tree mass } \\
m(\mathrm{~kg} \mathrm{dw})\end{array}$ & $\begin{array}{l}\text { Surface area } \\
\left(\mathrm{m}^{2} \text { tree }^{-1}\right)\end{array}$ \\
\hline 1 & \multicolumn{5}{c}{1.60} & 0.111 & 0.112 \\
2 & 1.26 & 1.91 & 0.197 & 0.224 \\
3 & 1.54 & 2.10 & 0.442 & 0.596 \\
4 & 2.71 & 3.20 & 1.947 & 1.942 \\
5 & 4.74 & 4.80 & 4.603 & 3.508 \\
6 & 4.75 & 5.50 & 5.024 & 6.660 \\
\hline
\end{tabular}


trees were made at a tree height, $H$, and stem diameter, $D_{0.1 \mathrm{H}}$, measured at a height of $H / 10$.

Respiration measurement. The respiration was nondestructively measured monthly throughout a year (from May 2007 to April 2008) with a modified enclosed standing tree method (cf. Ninomiya \& Hozumi 1983a, Yokota et al. 1994). The aerial parts of each sample tree were enclosed in a cylindrical chamber made of 0.1 to $0.2 \mathrm{~mm}$ thick polyvinyl chloride film. To avoid air leakage, potter's clay was applied to the base of the stem before tying the skirt of the chamber firmly to the stem base. A fan was installed to circulate the air inside the chamber to maintain a uniform $\mathrm{CO}_{2}$ concentration. $\mathrm{CO}_{2}$ increment and the temperature inside the chamber were measured using an infrared gas analyser (Carbon Dioxide Probe GMP343) installed inside the chamber. $\mathrm{CO}_{2}$ concentration was measured at $5 \mathrm{~s}$ intervals during a 10 to $30 \mathrm{~min}$ period. The monthly respiration measurement was completed within 1 night.

Respiration rate $r_{\theta}$ per tree $\left(\mu \mathrm{mol} \mathrm{CO}_{2} \mathrm{~s}^{-1}\right.$ tree $\left.{ }^{-1}\right)$ was calculated following the formula:

$$
r_{\theta}=V \cdot \frac{273.2}{273.2+\theta} \cdot \frac{P}{1013} \cdot \frac{1}{22.4} \cdot \Delta C
$$

where $V$ is the chamber volume (l) per tree, $\theta$ is the air temperature inside the chamber $\left({ }^{\circ} \mathrm{C}\right), P$ is the air pressure $(\mathrm{hPa})$ and $\Delta C$ is the $\mathrm{CO}_{2}$ increment rate (ppm $\mathrm{CO}_{2}$ $\mathrm{s}^{-1}$ ). The upper part of the chamber was cylindric and the lower part was shaped like a cone..

The $r_{\theta}$ was adjusted to the respiration rate $r$ at a monthly mean temperature considering the $Q_{10}$ value as 2 (Lambers et al. 2008), which is the rate of change in the respiration rate with a $10^{\circ} \mathrm{C}$ rise in temperature. Hence, $r$ was calculated following the formula:

$$
r=r_{\theta} \cdot Q_{10}{ }^{\frac{t-\theta}{10}}
$$

where $t$ is the mean temperature $\left({ }^{\circ} \mathrm{C}\right)$ of the month when the respiration was measured.

Measurement of mass. At the end of the study year, 13 sample trees (including 6 trees whose respiration were measured) representing different size classes available in the whole Manko Wetland were harvested to measure the individual aboveground mass $m$ (kg dry weight [dw]) per tree. A data set of 12 trees used in a previous paper (Khan et al. 2005) was added. As a result, data from 25 trees were used for the establishment of the allometric relationship. After the sample trees were felled, their $H(\mathrm{~m})$ and $D_{0.1 \mathrm{H}}(\mathrm{cm})$ were measured, and then the leaves and branches were separated from the stem. The fresh weight was measured for the stem, branches and leaves. Samples of the stem, branches and leaves were taken for estimating the ratio of dry/fresh mass. All samples were dried in a ventilated oven at $85^{\circ} \mathrm{C}$ for $72 \mathrm{~h}$, desiccated at room temperature and then weighed. As shown in Fig. 1, the resultant allometric relationship was given as:

$$
m=0.0341\left(D_{0.1 \mathrm{H}}^{2} H\right)^{1.03}
$$

\section{RESULTS}

\section{Size-dependence of respiration}

Examples of the dependence of the respiration rate $r$ $\left(\mu \mathrm{mol} \mathrm{CO}_{2} \mathrm{~s}^{-1}\right)$ per tree on individual tree mass $m(\mathrm{~kg}$ [dw]) are shown in Fig. 2. The dependence was successfully described with a power-functional relationship throughout a year $\left(0.50 \leqq \mathrm{R}^{2}(m, r) \leqq 0.88\right)$. The relationship is written as follows:

$$
r=f m^{h}
$$

where $f$ is the multiplying coefficient and $h$ is the scaling exponent specific to months. The value of $h$ for each month is shown in Table 2. The highest value of $h, 1.085$, was found in January and the lowest value, 0.723 , was found in July.

\section{Temperature-dependence of the exponent $h$}

A significance probability of the value of $h$ was examined for the null hypothesis $h=1.0$ (Ninomiya \&

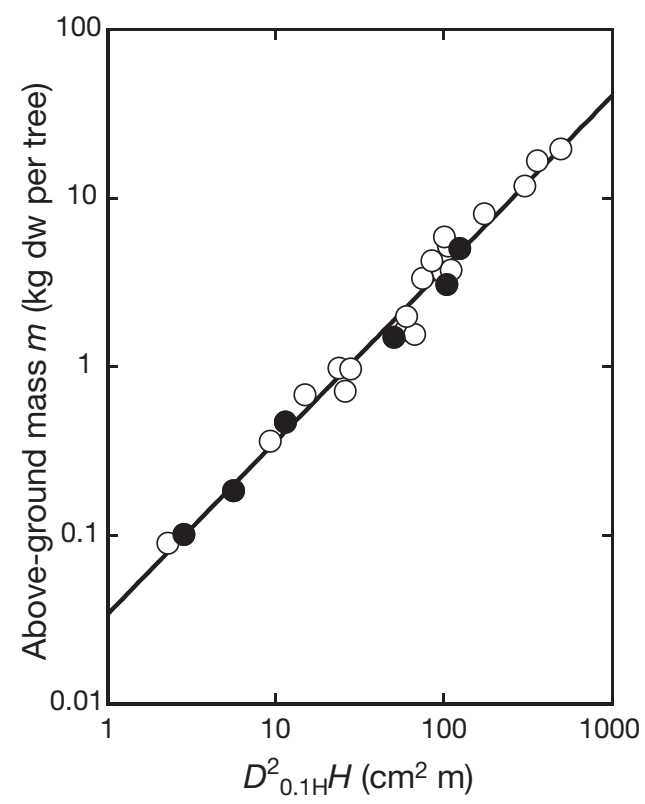

Fig. 1. Kandelia obovata. Allometric relationship of aboveground mass $m$ to $D_{0.1 \mathrm{H}}^{2} \mathrm{H}$ of trees $\left[R^{2}\left(D_{0.1 \mathrm{H}}^{2} H, m\right]=0.97\right)$. The straight line is given by Eq. (3). $\bullet$ : sample trees of respiration measurement; $\mathrm{O}$ : trees other than respiration measurement 


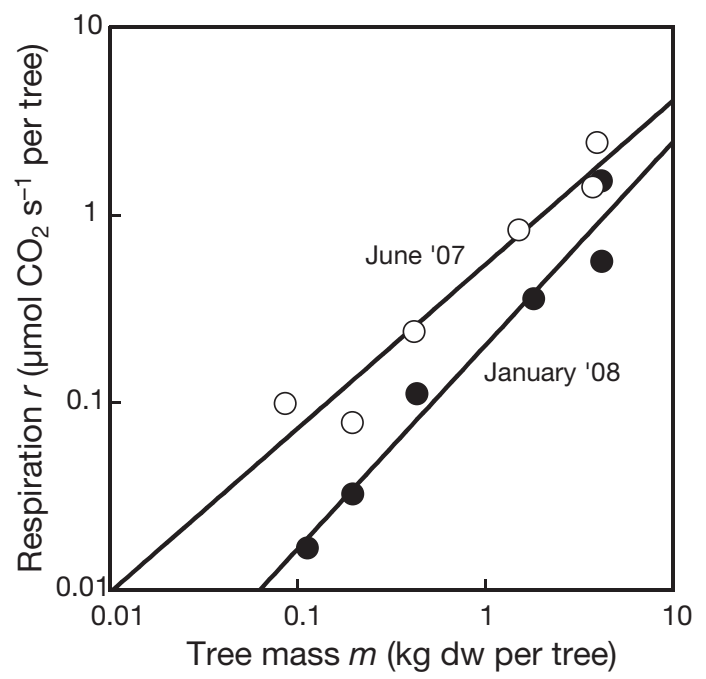

Fig. 2. Kandelia obovata. Power-functional relationship between respiration $r$ and tree mass $m$. The straight lines are given by Eq. (4). O: June 2007, $R^{2}(m, r)=0.88$; ๑: January $2008, R^{2}(m, r)=0.71$

Hozumi 1981, Reich et al. 2006), $3 / 4$ (West et al. 1999) and 2/3 (Ninomiya \& Hozumi 1983a,b, Hagihara et al. 1989), as compiled in Table 2 . No values were significantly different from $1.0,3 / 4$ or $2 / 3$ at a significance level of 0.01 . However, there was a clear trend that in the cool dormant season (when temperatures are below the mean annual temperature of ca. $24^{\circ} \mathrm{C}$ ) $h$ was closer to 1.0 than to $3 / 4$ and $2 / 3$, whereas in the warm growing season (when temperatures are above ca. $24^{\circ} \mathrm{C}$ ) $h$ was closer to $3 / 4$ than to 1.0 and $2 / 3$ except for October. These results support the dominance of the $3 / 4$ power scaling in the warm growing season and the isometric scaling in the cool dormant season. In addition, June was the transition period from the cool dormant season to the warm growing season, whereas October was the transition period from the warm growing season to the cool dormant season, because in these 2 months the significance probabilities for the null hypotheses $h=1.0$ and $h=3 / 4$ were almost similar.

The seasonal trend of monthly mean temperature $t$ and the scaling exponent $h$ of Eq. (4) is shown in Fig. 3. The exponent value increased rapidly from summer (July), reached a maximum value in winter (January) and decreased abruptly from winter to summer. In contrast, the temperature tended to decrease from July $\left(29.6^{\circ} \mathrm{C}\right)$ to February $\left(16.1^{\circ} \mathrm{C}\right)$, and then increased from February to July. This indicates a reverse trend between 2 variables. The exponent $h$ significantly

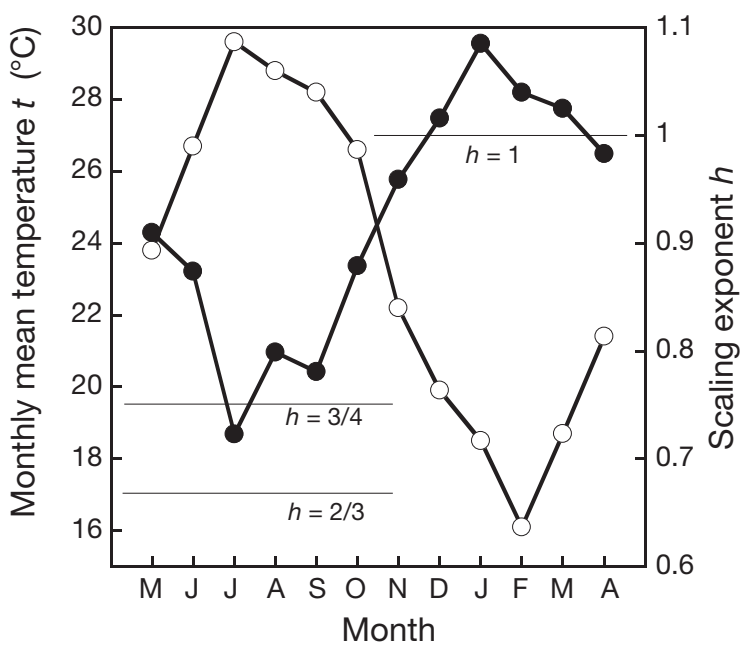

Fig. 3. Kandelia obovata. Monthly trends of the mean temperature $t$ of the month when tree respiration was measured, and of the exponent $h$ of Eq. (4). O: temperature; O: exponent. Horizontal lines stand for $h=1.0,3 / 4$ and $2 / 3$

Table 2. Scaling exponent of the power equation and its significance probability for the null hypotheses. Temperature is the mean temperature of the month when respiration was measured. The multiplying coefficient $f$ and scaling exponent $h$ of Eq. (4) are shown as mean \pm SE. Numbers in bold: highest significance probability for the null hypotheses

\begin{tabular}{|c|c|c|c|c|c|c|}
\hline \multirow[t]{2}{*}{ Month } & \multirow{2}{*}{$\begin{array}{c}\text { Temperature } \\
\left({ }^{\circ} \mathrm{C}\right)\end{array}$} & \multirow{2}{*}{$\ln f \pm \mathrm{SE}$} & \multirow[t]{2}{*}{$h \pm \mathrm{SE}$} & \multicolumn{3}{|c|}{ Probability for null hypothesis of $h$} \\
\hline & & & & 1.0 & $3 / 4$ & $2 / 3$ \\
\hline May 2007 & 23.8 & $-3.047 \pm 0.144$ & $0.910 \pm 0.097$ & 0.407 & 0.176 & 0.069 \\
\hline June 2007 & 26.7 & $-3.056 \pm 0.162$ & $0.874 \pm 0.109$ & 0.313 & 0.319 & 0.135 \\
\hline July 2007 & 29.6 & $-3.344 \pm 0.215$ & $0.723 \pm 0.144$ & 0.127 & 0.860 & 0.732 \\
\hline Aug 2007 & 28.8 & $-3.349 \pm 0.174$ & $0.799 \pm 0.117$ & 0.162 & 0.696 & 0.332 \\
\hline Sep 2007 & 28.2 & $-3.330 \pm 0.273$ & $0.781 \pm 0.180$ & 0.292 & 0.870 & 0.570 \\
\hline Oct 2007 & 26.6 & $-3.561 \pm 0.272$ & $0.879 \pm 0.180$ & 0.541 & 0.510 & 0.380 \\
\hline Nov 2007 & 22.2 & $-3.763 \pm 0.229$ & $0.959 \pm 0.159$ & 0.811 & 0.258 & 0.142 \\
\hline Dec 2007 & 19.9 & $-4.021 \pm 0.225$ & $1.016 \pm 0.156$ & 0.925 & 0.164 & 0.091 \\
\hline Jan 2008 & 18.5 & $-4.049 \pm 0.162$ & $1.085 \pm 0.112$ & 0.490 & 0.040 & 0.021 \\
\hline Feb 2008 & 16.1 & $-4.155 \pm 0.186$ & $1.040 \pm 0.128$ & 0.772 & 0.086 & 0.045 \\
\hline Mar 2008 & 18.7 & $-3.957 \pm 0.141$ & $1.025 \pm 0.097$ & 0.808 & 0.047 & 0.022 \\
\hline Apr 2008 & 21.4 & $-4.137 \pm 0.175$ & $0.983 \pm 0.120$ & 0.895 & 0.123 & 0.059 \\
\hline
\end{tabular}


decreased with increasing temperature $t: r(t, h)=0.96$, $\mathrm{p}<0.01$. On the other hand, the coefficient $f$ significantly increased with increasing $t: r(t, \ln f)=0.86, \mathrm{p}<$ 0.01 .

As shown in Fig. 4, the respiration rate of each individual tree was examined for the monthly mean temperature. In every individual, the respiration increased with increasing temperature. For each individual, the respiration $r$ was successfully formulated with an exponential function of the temperature $t$ :

$$
r=r_{0}{ }^{k t}
$$

where $r_{0}$ and $k$ are coefficients. The $k$-value is an indicator of the sensitivity of respiration to temperature or seasonality. Higher $k$-values indicate higher respiration with increasing temperature. The $k$-value ranged from 0.034 to $0.149^{\circ} \mathrm{C}^{-1}$, and its logarithmic value significantly decreased with an increase of the logarithmic value of tree mass: $r(\ln m, \ln k)=0.81, \mathrm{p}<0.01$ (Fig. 5).

\section{DISCUSSION}

\section{Size-dependence of metabolism}

Von Bertalanffy (1957) stated 3 forms of size-dependence of metabolism: the metabolic rate is (1) proportional to surface area $m^{2 / 3},(2)$ proportional to mass $m$ and (3) proportional to one intermediate between surface area and mass. All 3 patterns have been observed

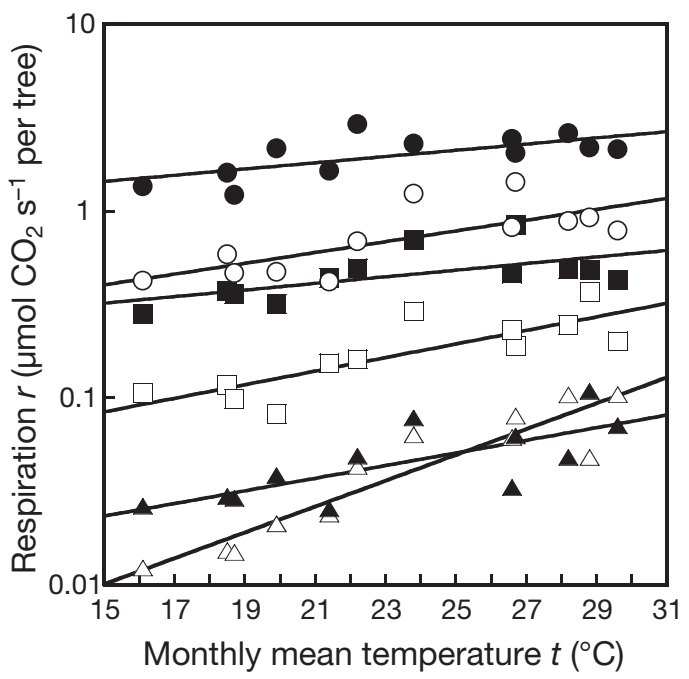

Fig. 4. Kandelia obovata. Exponential relationships between respiration $r$ and monthly mean temperature $t$ in differentsized trees (no. 1 to 6). The straight lines are given by Eq. (5). $\Delta:$ no. $1, R^{2}(t, r)=0.71 ; \boldsymbol{\Delta}:$ no. $2, R^{2}(t, r)=0.50 ; \square:$ no. 3 , $R^{2}(t, r)=0.50 ; \square:$ no. $4, R^{2}(t, r)=0.14$; O: no. $5, R^{2}(t, r)=0.27$; : no. $6, R^{2}(t, r)=0.45$

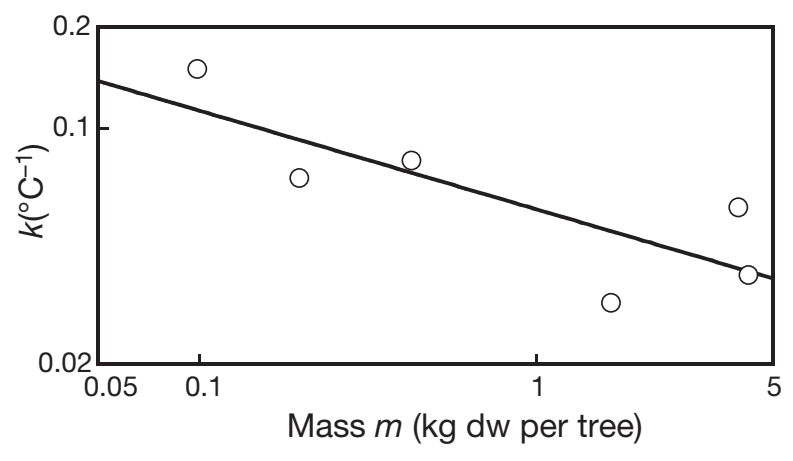

Fig. 5. Kandelia obovata. Relationship between the coefficient $k$ of Eq. (5) and mass $m$

in trees. On the one hand, Ninomiya \& Hozumi $(1983 a, b)$ found in a stand of 24 yr old Chamaecyparis obtusa (Seib. et Zucc.) Endl. during a self-thinning stage that the annual respiration of individual trees is nearly proportional to their surface area in large-sized trees, with the exception of smaller trees that were not undergoing self-thinning at the time. The self-thinning results from respiration surpassing photosynthesis, i.e. bankruptcy (Yokota \& Hagihara 1996). On the other hand, Ninomiya \& Hozumi (1981), Ogawa et al. (1985) and Yokota et al. (1994) all found that the annual respiration of individual trees is proportional to their mass in young conifer stands ( $<10$ yr old). In a broad summary of studies covering many species, Reich et al. (2006) also showed that whole-plant respiration rate scales are approximately proportional to total mass. Hagihara \& Hozumi (1991) suggested that in a young stand the annual respiration per tree may be directly proportional to its mass, because the heartwood is still active in young trees. However, in a mature stand the annual respiration per tree is proportional to its surface area, because active cells concentrate near the sapwood. In our experiment, the monthly exponent ranged from 0.723 to 1.085 (Table 2); this range is in agreement with the third statement of von Bertalanffy (1957).

\section{Seasonal dependence of respiration scaling}

In the warm summer (growing season), $h$ was closer to $3 / 4$ than to 1.0 or $2 / 3$ (Table 2) except in October. Since Kandelia ovobata in southern Japan is at the northernmost limit of its distribution (Spalding et al. 1997), the warm summer is favourable for K. obovata. As a result, the assumption of Brown et al. (2004) holds for the mangrove species in the higher temperature range, i.e. respiration is constrained by resource delivery through internal branching networks in the mangrove. Under optimal growth conditions when the re- 


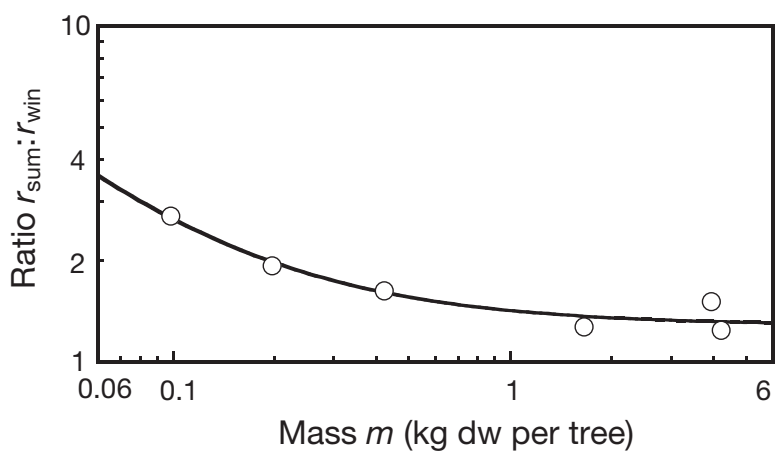

Fig. 6. Kandelia obovata. Relationship between the ratio of mean summer respiration $r_{\text {sum }}$ to mean winter respiration $r_{\text {win }}$ and mass $m$

source supply matches the demand, respiration rate scales to the $3 / 4$ power of biomass (Banavar et al. 2002).

In the cool winter (dormant season), $h$ was closer to 1.0 than to $3 / 4$ or $2 / 3$ (Table 2 ). The whole respiration is the combination of growth respiration proportional to absolute growth rate and maintenance respiration proportional to mass (Hesketh et al. 1971). Since the absolute growth rate is almost zero for the mangrove species during the winter season, the growth respiration is negligible. This means that the respiration mainly consists of maintenance respiration alone, so that the respiration might be proportional to $m$, rather than $\mathrm{m}^{3 / 4}$. Under resource limiting conditions, organisms must allocate an increasing proportion of their internal resources and total biomass towards resource acquisition. An increase in the ability to harvest resources with body size might lead to an increase in the scaling exponent of individual based respiration rate (Finkel et al. 2004).

The relationship between the ratio of mean summer respiration $r_{\text {sum }}$ (June to September) to mean winter respiration $r_{\text {win }}$ (October to May) and tree mass $m$ is shown in Fig. 6. The $r_{\text {sum }}$ was higher than $r_{\text {win }}$ in the whole range of $m$. The ratio $r_{\text {sum }}: r_{\text {win }}$ decreased in inverse proportion to increasing mass $m$ and then gradually approached a minimum asymptote of 1.24. Respiration is more sensitive to seasonal temperature in the small-sized trees, i.e. suppressed trees, than in the large-sized trees (Fig. 5). As a result, a relative decrease in respiration from the warm summer to the cool winter is larger in the small-sized trees than in the large-sized trees.

\section{CONCLUSIONS}

The respiration of Kandelia obovata increased with increasing size. The size-dependence (Fig. 2) was expressed with a power-function of Eq. (4) throughout a year (Table 2). The monthly exponent was higher in the cool winter (dormant season), whereas it was lower in the warm summer (growing season). The present study site, where the mean annual temperature is $23.4 \pm 0.1^{\circ} \mathrm{C}$, is closer to the northernmost distribution limit of $K$. ovobata, so that seasonal temperature may affect such dependence. Another explanation of this dependence is that in winter the main component of respiration is maintenance respiration, which is proportional to mass $m$, so that the amount of respiration is proportional to the mass of respiring tissue. However, during summer, woody tissues are growing, and woody tissue growth occurs at the surfaces, so that woody tissue growth respiration may be proportional to the surface area; i.e. to $\mathrm{m}^{2 / 3}$. Since maintenance respiration of both leaves and stems continues through the summer, total respiration (maintenance plus growth) scales somewhere between mass and surface area. However, the present experiment indicates that the separation of maintenance and growth respiration is necessary to better understand the dependence of respiration on size and temperature.

Acknowledgements. We are grateful to our colleagues, Drs. S. M. Feroz and K. Analuddin, Messrs. Y. Mori and D. Takagi, and Ms. N. Ferdousee for their cooperation and active participation in the field work. This study was financed in part by a Grant-in-Aid for Scientific Research (No. 20510011) from the Ministry of Education, Culture, Sports, Science and Technology, Japan, and by the 21st Century COE program of University of the Ryukyus.

\section{LITERATURE CITED}

Alongi DM (2009) The energetics of mangrove forests. Springer, London

Analuddin K, Suwa R, Hagihara A (2009) The self-thinning process in mangrove Kandelia obovata stands. J Plant Res 122:53-59

Atkin OK, Bruhn D, Hurry VM, Tjoelker MG (2005a) The hot and the cold: unravelling the variable response of plant respiration to temperature. Funct Plant Biol 32:87-105

Atkin OK, Bruhn D, Tjoelker MG (2005b) Response of plant respiration to changes in temperature: mechanisms and consequences of variations in $\mathrm{Q}_{10}$ values and acclimation. In: Lambers $\mathrm{H}$, Ribas-Carbo $\mathrm{M}$ (eds) Plant respiration: from cell to ecosystem. Springer, Dordrecht, p 95-135

Banavar JR, Damuth J, Maritan A, Rinaldo A (2002) Supplydemand balance and metabolic scaling. Proc Natl Acad Sci USA 99:10506-10509

Brown JH, Gillooly JF, Allen AP, Savage VM, West GB (2004) Toward a metabolic theory of ecology. Ecology 85: 1771-1789

Bruhn D, Schortemeyer M, Edwards EJ, Egerton JJG, Hocart CH, Evans JR, Ball MC (2008) The apparent temperature response of leaf respiration depends on the timescale of measurements: a study of two cold climate species. Plant Biol 10:185-193

Christensen B (1978) Biomass and primary production of Rhizophora apiculata Bl. in a mangrove in southern Thailand. Aquat Bot 4:43-52 
Clough BF (1998) Mangrove forest productivity and biomass accumulation in Hinchinbrook Channel, Australia. Mangr Salt Marsh 2:191-198

Finkel ZV, Irwin AJ, Schofield O (2004) Resource limitation alters the $3 / 4$ size scaling of metabolic rates in phytoplankton. Mar Ecol Prog Ser 273:269-279

Glazier DS (2005) Beyond the '3/4-powerlaw': variation in the intra- and interspecific scaling of metabolic rate in animals. Biol Rev Camb Philos Soc 80:611-662

Hagihara A, Hozumi K (1991) Respiration. In: Raghavendra AS (ed) Physiology of trees. John Wiley \& Sons, New York, p 87-110

Hagihara A, Paembonan SA, Hozumi K (1989) Respiration measurements of a hinoki (Chamaecyparis obtusa) tree for a three-year-period. Trans 100th Mtg Jpn For Soc, p 443-444

Hesketh JD, Baker DN, Duncan WG (1971) Simulation of growth and yield in cotton: respiration and the carbon balance. Crop Sci 11:394-398

Hoque ATMR, Suwa R, Mori S, Hagihara A (2009) Comparison of the size-dependence of aboveground respiration between Kandelia obovata and Bruguiera gymnorrhiza in Okinawa Island, Japan. In: Tropical forestry change in a changing world, Vol 6: mangrove and wetland ecosystems. Kasetsart University Faculty of Forestry, Bangkok, p 55-71

> Jarvis PG (1989) Atmospheric carbon dioxide and forests. Philos Trans R Soc Lond B Biol Sci 324:369-392

Khan MNI, Suwa R, Hagihara A (2005) Allometric relationships for estimating the aboveground phytomass and leaf area of mangrove Kandelia candel (L.) Druce trees in the Manko Wetland, Okinawa Island, Japan. Trees 19:266-272

Kira T (1991) Forest ecosystems of east and southeast Asia in a global perspective. Ecol Res 6:185-200

Kramer PJ, Kozlowski TT (1979) Physiology of woody plants. Academic Press, New York

Lambers H, Chapin FS III, Pons TL (2008) Plant physiological ecology, 2nd edn. Springer, New York

Larcher W (2003) Physiological plant ecology, 4th edn. Springer, Berlin

Ninomiya I, Hozumi K (1981) Respiration of forest trees (I). Measurement of respiration in Pinus densi-thunbergii Uyeki by an enclosed standing tree method. J Jpn For Soc 63:8-18

Ninomiya I, Hozumi K (1983a) Respiration of forest trees (II).

Editorial responsibility: Hans Heinrich Janssen,

Oldendorf/Luhe, Germany
Measurement of nighttime respiration in a Chamaecyparis obtusa plantation. J Jpn For Soc 65:193-200

Ninomiya I, Hozumi K (1983b) Respiration of forest trees (III). Estimation of community respiration. J Jpn For Soc 65: $275-281$

Ogawa K, Hagihara A, Hozumi K (1985) Growth analysis of a seedling community of Chamaecyparis obtuse (I). Respiration consumption. J Jpn For Soc 67:218-227

$>$ Ong JE (1993) Mangroves - a carbon source and sink. Chemosphere 27:1097-1107

Pallardy SG (2008) Physiology of woody plants, 3rd edn. Academic Press, London

Reich PB, Tjoelker MG, Machado JL, Oleksyn J (2006) Universal scaling of respiratory metabolism, size and nitrogen in plants. Nature 439:457-461

> Ryan MG (1991) The effect of climate change on plant respiration. Ecol Appl 1:157-167

Sheue C, Liu H, Yong JWH (2003) Kandelia obovata (Rhizophoraceae), a new mangrove species from Eastern Asia. Taxon 52:287-294

Spalding M, Blasco F, Field C (eds) (1997) World mangrove atlas. The International Society for Mangrove Ecosystems (ISME), Okinawa

Sprugel DG, Benecke U (1991) Measuring woody-tissue respiration and photosynthesis. In: Lassoie JP, Hinckley TM (eds) Techniques and approaches in forest tree ecophysiology. CRC Press, Boca Raton, FL, p 329-355

Sprugel DG, Ryan MG, Brooks JR, Vogt KA, Martin TA (1995) Respiration from organ level to the stand. In: Smith WK, Hinckley TM (eds) Resource physiology of conifers. Academic Press, San Diego, CA, p 255-299

Tomlinson PB (1986) The botany of mangroves. Cambridge University Press, Cambridge

> von Bertalanffy L (1957) Quantitative laws in metabolism and growth. Q Rev Biol 32:217-231

> West GB, Brown JH, Enquist BJ (1999) A general model for the structure and allometry of plant vascular systems. Nature 400:664-667

Yokota T, Hagihara A (1996) Dependence of the aboveground $\mathrm{CO}_{2}$ exchange rate on tree size in field-grown hinoki cypress (Chamaecyparis obtusa). J Plant Res 109:177-184

Yokota T, Ogawa K, Hagihara A (1994) Dependence of the aboveground respiration of hinoki cypress (Chamaecyparis obtusa) on tree size. Tree Physiol 14:467-479

Submitted: August 10, 2009; Accepted: January 20, 2010

Proofs received from author(s): March 30, 2010 